\title{
A EVOLUÇÃO DO CONTROLE JURISDICIONAL DA DISCRICIONARIEDADE ADMINISTRATIVA E SEUS REFLEXOS JURISPRUDENCIAIS
}

\section{THE EVOLUTION OF THE JUDICIAL CONTROL OF ADMINISTRATIVE DISCRETION AND ITS JURISPRUDENTIAL REFLECTIONS}

\section{LAURO ISHIKAWA}

Pós-Doutor na Universidade de Salamanca (USAL, Espanha). Mestre e Doutor em Direito pela Pontifícia Universidade Católica de São Paulo (PUC/SP). Coordenador Adjunto e Professor Permanente da Pós-Graduação Stricto Sensu (Mestrado e Doutorado) da Faculdade Autônoma de Direito (FADISP, São Paulo). Coordenador de Extensão e Professor das Faculdades Integradas Rio Branco (FRB, São Paulo). Professor da Escola de Direito da Universidade Anhembi Morumbi (UAM, São Paulo). Foi Membro do Conselho Superior da CAPES (2008-2010). Pesquisador bolsista da FUNADESP. Advogado em São Paulo. E-mail: lauro.ishikawa@unialfa.com.br

\section{CLÓVIS SMITH FROTA JÚNIOR}

Mestre em Direito pela Faculdade Autônoma de Direito (FADISP, São Paulo). Professor do Curso de Pós-Graduação Lato Sensu da Universidade Federal do Amazonas (UFAM). Ex-Procurador-Geral do Estado do Amazonas. Procurador do Estado do Amazonas. Advogado em Manaus. E-mail: clovisfrota@yahoo.com.br

\section{RESUMO}

O presente artigo discorre sobre a evolução do controle sobre os atos administrativos discricionários, em especial a sindicabilidade do "mérito" destes, perpassando as diferentes teorias surgidas, desde a consolidação da ideia de Estado de Direito. Logo 
após, discorre-se sobre a admissão do controle judicial quanto aos elementos vinculados do ato, e, em seguida, sobre esse controle a partir de parâmetros implícitos da lei. Posteriormente, discorre-se sobre a teoria da vinculação direta aos princípios e dos atos "vinculados" por conceitos jurídicos indeterminados. Por último, aborda-se a teoria do enfoque jurídico-funconal, para, então, concluir pela possibilidade de se verificar uma tendência de sistematização, no sentido de apontar alguns parâmetros para o controle jurisdicional da discricionariedade administrativa. É utilizado o método dedutivo, por meio de pesquisa realizada em legislação, doutrina e jurisprudência das Cortes Superiores.

PALAVRAS-CHAVE: Direito Administrativo; Ato Administrativo; Discricionariedade; Controle Jurisdicional; Mérito do Ato; Conveniência e Oportunidade.

\section{ABSTRACT}

This article discusses the evolution of the judicial control over discretionary administrative acts, especially the syndicability of the "merit" of these acts, crossing the different theories that have emerged since the consolidation of the idea of the rule of law. After discussing this judicial control in face of the rule of law, the admission of judicial control on the elements of the act is analyzed, and then, this control from implicit parameters of the law. Subsequently, there is a discussion of the theory of direct linkage to principles and "bound" acts by indeterminate legal concepts. Finally, it is discussed the theory of the legal-functional approach, and then, conclude that there is a tendency to systematize, in order to point out some parameters for the jurisdictional control of administrative discretion. The deductive method is used, through research conducted in legislation, doctrine and jurisprudence of the Superior Courts.

KEYWORDS: Administrative Law; Administrative Act; Discretion; Judicial Control; Merit of the Act; Convenience and Opportunity. 


\section{INTRODUÇÃO}

A questão relativa ao controle jurisdicional do mérito dos atos administrativos - ou, em sentido mais amplo, das escolhas administrativas - é assunto já por muito conhecido da doutrina, sem que se tenha chegado à consolidação de uma teoria ao menos amplamente majoritária.

Sem embargo dessa dificuldade, é relevante que sejam identificadas as principais teorias em debate. Faz-se esse cotejo no presente trabalho, a principiar pelo surgimento, no Séc. XIX, de construções teóricas a respeito da sindicabilidade dos atos administrativos discricionários, inclusive no plano jurisdicional, ao que se seguiram diversas outros aportes teóricos que findaram ora por ampliar os limites desse controle, a ponto de eliminar a discricionariedade, ora por buscar redimensionar a correlação de forças, reconhecendo uma esfera de atuação administrativa infensa ao controle jurisdicional.

Dessa maneira, se propõe a passar em revista algumas dessas teorias e, ainda, demonstrar os seus reflexos na jurisprudência do Superior Tribunal de Justiça e do Supremo Tribunal Federal. Para tanto, utiliza-se o método dedutivo, através de pesquisa qualitativa e exploratória, mediante consulta bibliográfica em documentos, obras e legislações nacionais e internacionais.

Em assim sendo, inicia-se abordando o conceito de discricionariedade ao qual se refere no momento.

\section{BREVES COMENTÁRIOS SOBRE O CONCEITO DE DISCRICIONARIEDADE}

O conceito de discricionariedade, consoante lição de Celso Antônio Bandeira de Mello (1998, p. 48):

[...] é a margem de liberdade que remanesça ao administrador para eleger, segundo critérios consistentes de razoabilidade, um, dentre pelo menos dois comportamentos cabíveis, perante cada caso concreto, a fim de cumprir o dever de adotar a solução mais adequada à satisfação da finalidade legal, quando, por força da fluidez das expressões da lei ou da liberdade conferida no mandamento, dela não se possa extrair objetivamente, uma solução unívoca para a situação vertente. 
Observa-se que o conceito não engloba apenas a ideia de vinculação aos princípios, mas exprime o poder/dever de escolha do administrador público que deve ser exercitado com vistas à obtenção do resultado mais ajustado à finalidade legal.

Tratam-se das duas situações em que se expressam as competências discricionárias: fluidez das expressões da lei (conceitos jurídicos indeterminados) ou liberdade conferida no mandamento.

Há entendimento no sentido de não ser possível estabelecer associação necessária entre as ideias de conceitos jurídicos indeterminados e de discricionariedade stricto sensu (SILVA, 1990, p. 54), porém, muitas vezes conceitos indeterminados e discricionariedade são interligados, impedindo uma separação clara.

Com efeito, são relativamente escassos os casos em que a atuação administrativa se apresenta objetivamente predeterminada pelo texto legal, como ocorre com atos administrativos cuja edição depende apenas de cálculos matemáticos ou que trabalham com conceitos objetivos (KRELL, 2004, p. 184). Mais comuns são as leis que tratam conceitos legais, de natureza empírica e descritiva, como homem, animal, casa, óbito etc. (KRELL, 2004, p. 184). Finalmente - e aqui reside o ponto -, há normas mais abertas, que se valem de conceitos normativos, inclusive valorativos, como interesse público, idoneidade moral, bons costumes, urgência, notório saber etc. (KRELL, 2004, p. 184). É quanto a estes últimos que se costuma associar a ideia de discricionariedade, em algum grau.

Sem embargo, a discricionariedade administrativa pode ainda decorrer de expressa opção legislativa, como adverte Almiro do Couto e Silva (1990, p. 54), ao destacar que:

\footnotetext{
Ao fixarem as leis as diferentes competências dos órgãos do Estado, se muitas vezes indicam com exatidão milimétrica qual deverá ser a conduta do agente público, em numerosíssimas outras Ihes outorgam considerável faixa de liberdade, a qual pode consistir não só na faculdade de praticar ou de deixar de praticar certo ato, como também no poder, dentro dos limites legais, de escolher no rol das providências possíveis aquela que lhe parecer mais adequada à situação concreta. $\mathrm{O}$ elenco de providências, conforme dispuser a norma, poderá ser maior ou menor.
}

Desta feita, reconhece-se que não é possível contrapor diametralmente as 
noções de ato vinculado e de ato discricionário. O trajeto entre elas comporta graduação, como apontou Odete Medauar (2002, p. 130), ao ressaltar que "[...] no cotidiano das atividades administrativas, são poucas as situações de vinculação pura e de discricionariedade pura, daí ser insustentável a oposição rígida entre poder vinculado e poder discricionário".

\section{O ESTADO DE DIREITO E A IDEIA DE CONTROLE DOS ATOS DISCRICIONÁRIOS}

O advento do Estado de Direito altera o entendimento e o panorama sobre controle dos atos administrativos, sobretudo os discricionários. Num cenário em que a discricionariedade se confundia com a arbitrariedade, o governo com a Administração e a vontade do príncipe com a ordem jurídica, não se mostravam presentes os requisitos essenciais para a realização de tal escrutínio (BINENBOJM, 2014, p. 207-208).

O Estado de Direito surge, então, sob o pilar "de imposição de limites jurídicos às atividades dos órgãos estatais" (BINENBOJM, 2014, p. 208), reconhecendo-se autonomia às noções de governo, parlamento e Administração. Para Joseph Raz (1979, p. 212), o Estado de Direito, em seu sentido amplo, significa "[...] que as pessoas devem obedecer às leis e serem reguladas por elas. Porém, em uma teoria política e jurídica, ele deve ser lido de uma maneira mais estrita, no sentido de que o governo deve ser regulado pelas leis e submetido às mesmas."

É nesse cenário que começam a se desenvolver as teorias tendentes ao controle jurisdicional dos atos administrativos discricionários, a principiar pelo controle dos elementos vinculados do ato.

\subsection{CONTROLE QUANTO AOS ASPECTOS VINCULADOS DO ATO}

Relegada ao passado a concepção de que os atos discricionários são inteiramente infensos ao controle jurisdicional, o primeiro passo dado pela doutrina foi distinguir, dentre os elementos do ato administrativo, aqueles nos quais não se 
manifesta qualquer discricionariedade, de modo a reconhecer que, quanto a eles, a análise judicial é plena.

Para fins didáticos, os atos administrativos possuem cinco elementos: sujeito, forma, objeto, finalidade e motivo. Sujeito, segundo Maria Sylvia Di Pietro (2009, p. 203), "[...] é aquele a quem a lei atribui competência para a prática do ato". Forma, de seu turno, inclui não apenas "[...] a exteriorização do ato, mas também todas as formalidades que devem ser observadas durante o processo de formação da vontade da Administração, e até os requisitos concernentes à publicidade do ato" (DI PIETRO, 2009, p. 207). O objeto, segundo Celso Antônio Bandeira de Mello (2011, p. 397-398), "[...] é aquilo sobre que o ato dispõe, isto é, o que o ato decide, certifica, opina ou modifica na ordem jurídica. É, em suma, a própria medida que produz a alteração na ordem jurídica". O quarto elemento, o motivo, expressa as razões de fato e de direito que ensejam ou autorizam a prática do ato. Finalmente, a finalidade "[...] é o resultado que a Administração quer alcançar com a prática do ato" (DI PIETRO, 2009, p. 209).

A discricionariedade, por outro lado, residiria no objeto ou no motivo; logo, vícios relativos ao sujeito (competência), à forma e à finalidade seriam, assim, plenamente sindicáveis, pois o seu exame não adentraria no mérito administrativo. Ademais, "[...] o motivo e objeto, quando não fixados previamente pela lei, seriam elementos cuja apreciação pelo Poder Judiciário encontrava-se limitada" (BINENBOJM, 2014, p. 214). É uma teoria, portanto, que preserva o mérito do ato administrativo, afastando o controle a seu respeito'.

$\mathrm{Na}$ jurisprudência atual, o controle quanto a aspectos vinculados dos atos discricionários diz respeito, em regra, à respectiva forma, mais precisamente à necessidade de motivação, e à competência. De todo modo, é possível afirmar que o controle judicial dos atos discricionários, tomando como ponto de partida os aspectos vinculados do ato, é medida praticada ainda hoje e certamente é daquelas que menos questionamentos suscita.

\footnotetext{
1 Há autores, como Germana de Oliveira Moraes (2004, p. 59), que incluem no controle dos aspectos vinculados do ato administrativo o exame a respeito do chamado desvio de poder, do erro de fato e do erro de direito, numa concepção claramente mais abrangente a respeito dos elementos vinculados.
} 


\subsection{CONTROLE A PARTIR DE PARÂMETROS IMPLÍCITOS DA LEI}

O controle a partir de parâmetros implícitos da lei engloba, segundo a lição de Gustavo Binenbojm (2014, p. 211), institutos voltados para o controle dos atos discricionários que já permitem, em algum grau, o exame do mérito administrativo. Nessa classe incluem-se as figuras do desvio de poder e a teoria dos motivos determinantes.

O referido autor faz alusão ainda ao vício do excesso de poder, mas este, como adverte Queiró (1946, p. 68), "[...] é um vício complexo, que, além da 'usurpação de poderes' compreende ainda o chamado 'desvio de poder". Como apenas este último diz respeito aos aspectos discricionários do ato - já que a competência é sempre vinculada -, não há interesse aqui em examinar a figura da usurpação de poderes.

O desvio de poder, segundo aponta Caio Tácito (1992, p. 64), representa um limite à ação discricionária, ao "[...] impedir que a prática do ato administrativo, calcada no poder de agir do agente, possa dirigir-se à consecução de um fim de interesse privado, ou mesmo de outro fim público estranho à previsão legal". A ideia subjacente ao instituto é a de que a ação administrativa deve sempre perseguir a consecução da finalidade legal, e não desígnios pessoais ou mesmo públicos, se estranhos ao comando legal (SILVA, 1990, p. 63).

Marcelo Caetano, citado por Afonso Queiró (1946, p. 69), aponta que "[...] o ato viciado de desvio de poder é aparentemente regular: o único dos seus elementos essenciais atingidos pela ilegalidade é o fim, que não é visado pela lei. Violou-se o espírito da lei".

Tal teoria teve origem na jurisprudência do Conselho de Estado francês, como détoumement de pouvoir, a partir do famoso caso Lesbats, decidido em 1864, em que se chegou à conclusão de que o ato da autoridade praticado no uso de seus poderes, mas buscando fim diverso daquele previsto na regra de competência, configura desvio de poder (TÁCITO, 1992, p. 64).

A acolhida dessa doutrina pelo Direito brasileiro se deve não apenas à doutrina e à jurisprudência, como à própria iniciativa do legislador. A Lei da Ação Popular (Lei n. 4.717/65), em seu artigo 2., alínea "a", prescreve que: esta-se diante 
de uma nulidade quando o agente pratica o ato visando a fim diverso daquele previsto, explícita ou implicitamente, na regra de competência.

Interessante notar que, já nesse contexto de mudança de entendimento acerca do controle dos atos discricionários, era possível identificar vozes na doutrina que se preocupavam com o exercício desse tipo de controle, vendo nele o risco de mero deslocamento da discricionariedade. Como apontada Afonso Queiró (1946, p. 64), "o controle do détournement de pouvoir implica, as mais das vezes, para o juiz o exercício de um poder discricionário".

No direito brasileiro, o leading case na matéria é representado pelo julgamento da Apelação Cível n. 1.422, no Tribunal de Justiça do Rio Grande do Norte, sob a relatoria do Desembargador Seabra Fagundes. Àquela altura, a doutrina francesa foi invocada para impedir que, "[...] a pretexto de encontrar-se em exercício de um poder discricionário, a Administração Pública protegesse uma empresa de transporte em prejuízo da concorrente e dos usuários do sistema autorizado" (BINENBOJM, 2014, p. 216).

Ainda hoje a doutrina do desvio de poder é largamente aceita pela jurisprudência brasileira, embora muitas vezes se recuse a invalidação do ato por falta de arguição ou prova a respeito da sua ocorrência. Nesse sentido, o Superior Tribunal de Justiça decidiu, inter plures, sob a relatoria do Ministro Carlos Velloso, acerca dos atos de manutenção ou extinção de estabelecimentos militares que situam-se no campo da discricionariedade administrativa. Pois "inexistente alegação no sentido de que teria havido desvio de finalidade ou abuso de poder na pratica do ato discricionário, escapa este do controle judicial” (BRASIL, 1989, p. 15.334).

Noutro julgamento, estabelecendo uma correlação entre o exercício do poder de polícia e a discricionariedade, sob relatoria do Ministro João Otávio de Noronha, entendeu-se que "a discricionariedade que caracteriza o poder de polícia da Administração deve estar contida nos limites estabelecidos na lei, devendo a autoridade observar atentamente essas limitações, sob pena de incidir em arbitrariedade, por abuso ou desvio de poder" (BRASIL, 2007, p. 184). Ipso facto, "age com abuso e desvio de poder o agente público que realiza despesas sem a devida previsão orçamentária" (BRASIL, 1998, p. 109).

Acerca da teoria dos motivos determinantes, deve-se em princípio considerar 
que está superada atualmente a ideia de que os atos discricionários independem de motivação, i.e., da explicitação das razões de fato e de direito que levaram a autoridade administrativa a agir de tal ou qual forma. Como destaca Adilson Dallari (1986, p. 57), "[...] exatamente porque eu posso decidir de diferentes maneiras é que eu preciso deixar bem claro porque estou decidindo desta determinada maneira, e não de outra". Não por outra razão a jurisprudência tem invalidado atos discricionários vindos à lume sem a devida e congruente exposição de motivos (BRASIL, 2011a, p. 157).

À medida que $\mathrm{o}$ ato discricionário deve ser motivado, a teoria dos motivos determinantes preconiza que a respectiva validade fica condicionada à existência e à pertinência dos motivos apontados pela autoridade administrativa. Como se vê na jurisprudência do Superior Tribunal de Justiça "[...] os motivos que determinam a vontade do agente público, consubstanciados nos fatos que serviram de suporte à sua decisão, integram a validade do ato, eis que a ele se vinculam visceralmente. É o que reza a prestigiada teoria dos motivos determinantes" (BRASIL, 2002, p. 183) .

Não é o caso de se exigir que os motivos sejam razoáveis ou proporcionais. Tais atributos dizem respeito a princípios constitucionais derivados do due process of law (CF, art. 5., LIV), em sentido substancial, e, portanto, ingressam no capítulo seguinte, o qual trata diretamente do controle dos atos discricionários por vinculação direta aos princípios.

Assim, continuando, a jurisprudência, forte na teoria dos motivos determinantes, também já é composta de julgado em torno da validade de questão de concurso público. Nessa decisão, o STJ manteve o argumento do TRF da 5. a Região, que anulara questão de concurso público, tendo em vista que "[...] o próprio doutrinador que a comissão examinadora invocou para justificar a validade da questão afirmou, pessoalmente, que a questão é nula" (BRASIL, 2014a).

Ademais, dentre outras decisões merecedoras de referência está o julgamento do Agravo Regimental em REsp n. 1.280.729/RJ, sob a relatoria do Ministro Humberto Martins. Nesse caso, a 2.. Turma do STJ (BRASIL, 2012) fundamentou, primeiro, pela sindicabilidade dos atos discricionários, quanto a aspectos formais e materiais, "[...] cabendo observar que os motivos embasadores dos atos administrativos vinculam a Administração, conferindo-Ihes legitimidade e 
validade". Diante disso, entendeu-se que:

[...] se o ato administrativo de avaliação de desempenho confeccionado apresenta incongruência entre parâmetros e critérios estabelecidos e seus motivos determinantes, a atuação jurisdicional acaba por não invadir a seara do mérito administrativo, porquanto limita-se a extirpar ato eivado de ilegalidade. (BRASIL, 2012).

Finalmente, no julgamento do REsp 725.537/RS, sob a relatoria do Ministro Félix Fischer, a 5 ${ }^{\mathrm{a}}$ Turma do STJ assentou que 0 ato de licenciamento de militar temporário é discricionário, mas isso não impede o seu escrutínio jurisdicional e, mais especificamente, que "[...] é possível a sua anulação quando o motivo que o consubstancia está eivado de vício" (BRASIL, 2005b, p. 621).

Vê-se, portanto, que das teorias em voga quanto ao controle dos atos administrativos, inclusive dos atos discricionários, a teoria dos motivos determinantes está certamente dentre aquelas de maior consagração jurisprudencial.

\section{TEORIA DA VINCULAÇÃO DIRETA AOS PRINCÍPIOS}

A despeito dos avanços representados pelas teorias apontadas, a doutrina entendia que tal evolução ainda era "[...] insuficiente para dar conta da significativa gama de arbitrariedades perpetradas sob o manto do mérito administrativo" (BINENBOJM, 2014, p. 219). Nesse ensejo, surge a teoria da vinculação direta dos atos administrativos aos princípios, compreendida como "[...] a mais articulada e importante resposta à demanda por maior controle judicial sobre as margens de apreciação e escolha da Administração Pública" (BINENBOJM, 2014, p. 219).

$\mathrm{O}$ advento do pós-positivismo possui como um de seus traços marcantes a ascensão dos princípios (BARROSO; BARCELOS, 2003, p. 30-33), aos quais se reconhece quatros diferentes modalidades de eficácia: (a) positiva ou simétrica, (b) interpretativa, (c) negativa e (d) vedativa do retrocesso (BARROSO; BARCELOS, 2003, p. 57). A eficácia positiva dos princípios se traduz na ideia de que todos, inclusive a Administração, estão subordinados não apenas à lei, em sentido estrito, mas também aos princípios, sobretudo os constitucionais. Destarte, a eficácia 
negativa "[...] autoriza que sejam declaradas inválidas todas as normas ou atos que contravenham os efeitos pretendidos pela norma" (BARROSO; BARCELOS, 2003, p. $58)$.

Por consequência, a ideia de princípio da legalidade passa a ser substituída, portanto, pela de princípio da juridicidade, de sorte que, como aponta Gustavo Binenbojm (2014, p. 220) não se pode mais "[...] falar, tecnicamente, numa autêntica dicotomia entre atos vinculados e atos discricionários, mas, isto sim, em diferentes graus de vinculação dos atos administrativos à juridicidade" (itálico nosso). Surge, pois, uma escala decrescente de "densidade normativa vinculativa" (BINENBOJM, 2014, p. 220): (i) atos vinculados por regras (constitucionais, legais ou regulamentares); (ii) atos vinculados por conceitos jurídicos indeterminados (constitucionais, legais ou regulamentares); e (iii) atos vinculados diretamente por princípios (constitucionais ou legais).

Fica claro que a "principialização do direito brasileiro acabou por aumentar a margem de vinculação dos atos discricionários à juridicidade" (BINENBOJM, 2014, p. 224), pois "o mérito - núcleo do ato -, antes intocável, passa a sofrer a incidência direta dos princípios constitucionais" (BINENBOJM, 2014, p. 221). Logo, o mérito do ato administrativo experimenta um evidente estreitamento, surgindo inclusive construções teóricas que sustentam a ideia de redução da discricionariedade a zero.

Antes de analisar as subteorias relativas aos conceitos jurídicos indeterminados e da redução da discricionariedade a zero, cumpre aludir que a jurisprudência tem acolhido largamente o emprego dos princípios constitucionais e legais como limites jurídicos para a discricionariedade administrativa.

Assim, o exame dos motivos do ato, segundo Maria Sylvia Zanella Di Pietro (2012), experimentou ampliação ao longo do desenvolvimento da teoria, sendo possível identificar três estágios bem claros:

[...] de início, fazia-se apenas uma constatação dos fatos, para saber se existiram ou não; em um segundo momento, passou-se a examinar a qualificação jurídica dos fatos feita pela Administração, para verificar se os fatos ocorridos são de natureza a justificar a decisão, permitindo-se ao Judiciário entrar no exame das noções imprecisas ou "conceitos jurídicos indeterminados"; em uma terceira fase, passou-se a examinar a adequação da decisão aos fatos, pela aplicação dos princípios da proporcionalidade dos meios aos fins. 
No julgamento do REsp 443.310/RS, sob a relatoria do Ministro Luiz Fux, a 1. - Turma do Superior Tribunal de Justiça decidiu que os atos discricionários estão submetidos a controle à luz dos princípios da proporcionalidade e razoabilidade. Como consta da ementa do julgado, "[...] a atuação da Administração Pública, deve seguir os parâmetros da razoabilidade e da proporcionalidade, que censuram 0 ato administrativo que não guarde uma proporção adequada entre os meios que emprega e o fim que a lei almeja alcançar." (BRASIL, 2003, p. 249)

Enfocando tema relativo à responsabilidade disciplinar de servidor público, a

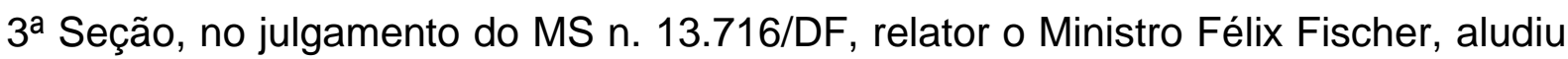
que "esta c. Corte pacificou entendimento segundo o qual, mesmo quando se tratar de imposição da penalidade de demissão, devem ser observados pela Administração Pública os princípios da razoabilidade e proporcionalidade" (BRASIL, 2008a).

Interessante questão foi levada a julgamento no REsp 778.648/PE, apreciado

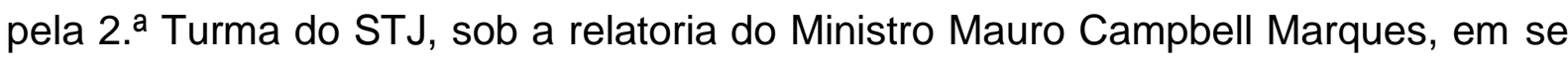
discutia a legitimidade do indeferimento, pela autoridade fiscal, de pedido de prova pericial formulado por contribuinte no curso de processo administrativo. Entendeu a Corte, inicialmente, que o Poder Judiciário pode controlar 0 mérito do ato administrativo sempre que a Administração Pública agir contrariamente ao princípio da razoabilidade. (BRASIL, 2008b)

Ainda segundo ele, se o único modo de se demonstrar o cumprimento do substrato fático da norma é através da realização de perícia, "fica fácil concluir que eventual oposição da Administração acaba violando o direito subjetivo constitucional do administrado-contribuinte ao devido processo legal" (BRASIL, 2008b).

Já no âmbito do Supremo Tribunal Federal, emblemático o julgamento do RE 898.450, sob regime de repercussão geral, em que o Plenário da Corte, na relatoria do Ministro Luiz Fux, entendeu - à luz dos princípios da igualdade, da dignidade da pessoa humana, da liberdade de expressão, da proporcionalidade e do livre acesso aos cargos públicos - que não se pode impedir o provimento de cargo público por pessoa com tatuagem. A ementa do julgado consigna, bem a propósito, que o "Estado de Direito republicano e democrático, impõe à Administração Pública que exerça sua discricionariedade entrincheirada [...] sobretudo, pelos direitos fundamentais em um ambiente de perene diálogo com a sociedade". (BRASIL, 2017) 
O mesmo Pleno do STF, ao julgar o RE 598.099, sob a relatoria do Ministro Gilmar Mendes, reconheceu o direito subjetivo à nomeação dos candidatos aprovados dentro da quantidade de vagas previstas no edital, baseado nos princípios da segurança jurídica, boa-fé e proteção à confiança. Assim, ficou definitivamente superada a concepção de que os aprovados possuíam mera expectativa de direito, a depender do critério de oportunidade e conveniência da Administração, sendo que tal solução foi construída a partir da vinculação direta aos princípios (BRASIL, 2011c).

\section{ATOS "VINCULADOS" POR CONCEITOS JURÍDICOS INDETERMINADOS}

Os conceitos jurídicos indeterminados, segundo a classificação proposta por Gustavo Binenbojm (2014, p. 221-225), representam uma "zona de vinculação intermediária entre a vinculação por regras e a vinculação direta por princípios". São conceitos que "requerem do intérprete da norma uma valoração" (BINENBOJM, 2014, p. 226), trabalhando com conceitos normativos, inclusive valorativos, como "interesse público", "idoneidade moral", "bons costumes", "urgência", "notório saber" etc. (KRELL, 2004, p. 184),

Necessário referir, contudo, que parcela respeitável da doutrina busca extremar as noções de competência discricionária e de aplicação de conceitos jurídicos indeterminados. Almiro do Couto e Silva (1990, p. 57-58) defende que os atos que aplicam conceitos jurídicos indeterminados estão sujeitos a um "controle jurisdicional limitado", mas que essa "impossibilidade relativa do controle judicial da aplicação dos conceitos jurídicos indeterminados pela Administração Pública não os transforma [...] em fonte de poder discricionário" (SILVA, 1990, p. 59). Assim, dispõe a diferença quanto à sindicabilidade judicial dos atos que aplicam conceitos indeterminados e dos atos discricionários:

(a) O exame judicial dos atos administrativos de aplicação de conceitos jurídicos indeterminados não está sujeito a um limite a priori estabelecido na lei. O próprio julgador, no instante de decidir, é que verificará se há um limite, ou não, ao controle judicial. [...] (b) O exame judicial de atos administrativos que envolvem exercício de poder discricionário está, a priori, limitado pela lei, a qual fixou desde logo as linhas dentro das quais poderá a autoridade administrativa livremente tomar suas decisões. Dentro daquele espaço, 
qualquer uma delas será juridicamente incensurável e inexaminável pela autoridade judiciária. (SILVA, 1990, p. 59).

A despeito desses questionamentos, prevalece - tanto no plano doutrinário quanto jurisprudencial - a concepção de que os conceitos jurídicos abertos, por conferirem ao administrador um poder de conformação que se manifesta no poder de escolha uma entre duas ou mais medidas, acaba por the conferir certo grau de discricionariedade.

\subsection{TEORIA DAS TRÊS ZONAS}

Fala-se em certo grau de discricionariedade quanto aos conceitos jurídicos indeterminados porque já há muito é conhecida a ideia de que os conceitos contemplam uma zona nuclear ou fixa (núcleo) e uma zona periférica (halo). Quando se tem uma noção clara do conceito, está-se no domínio do núcleo conceitual; quanto não, começa o halo do conceito" (MORAES, 2004, p. 64). Essa ideia, evoluiu para a chamada teoria das três zonas, segundo a qual nos conceitos jurídicos indeterminados seria possível identificar aquilo que certamente se inclui nele (zona de certeza positiva) e aquilo que certamente escapa aos seus limites (zona de certeza negativa), sem que isso afaste a existência de uma zona intermediária, que diz respeito àquelas situações em que é difícil precisar se a situação se ajusta à hipótese abstrata do conceito.

Não se propõe, por força dessa teoria, a imunidade jurisdicional dos atos praticados na interpretação de conceitos indeterminados. Como bem expõe Celso Antônio Bandeira de Mello (2011, p. 59), por mais vagas ou imprecisas que sejam as expressões legais qualificadoras dos motivos ou dos fins, "o Judiciário poderá e deverá sindicar o ato, averiguando se a significação nuclear do conceito sintonizado na palavra foi, ou não, respeitada".

Essa teoria das três zonas experimenta grande consagração jurisprudencial e se tem notícia do seu emprego - ou, ao menos, da noção jurídica subjacente a ela desde a década de 60, do século passado. Por exemplo, no julgamento do RE 62.731, discutia-se a constitucionalidade da purgação da mora em contratos de locação comercial por meio de decreto-lei, editado sob o pálio de "assuntos de segurança 
nacional".

Ante a dificuldade em definir o conceito de segurança nacional, o ministro Aliomar Baleeiro sustentou que, podemos dizer o que é "segurança nacional" por exclusão: "bola de futebol não é segurança nacional, batom de moça não é segurança nacional, cigarro de maconha não é segurança nacional”, tendo concluído que locação também não seria tema de segurança nacional. Ou seja, foi utilizada uma zona de certeza negativa do conceito, para a conclusão sobre a locação comercial (BRASIL, 1968, p. 559).

No mesmo sentido, 2. ${ }^{\text {a }}$ Turma do STJ, ao apreciar o Recurso Ordinário em Mandado de Segurança n. 1.751/PR, entendeu que não se insere no conceito de "interesse da justiça" a remoção por permuta de delegatário de serventias extrajudiciais motivada por nepotismo (zona de certeza negativa) (BRASIL, 1994a, p. 15.093).

Em caso que envolvia o preenchimento dos requisitos para o provimento do cargo de conselheiro do Tribunal de Contas do Tocantins, no julgamento do RE 167.137/TO, o STF entendeu pela invalidade da nomeação, pois realizada com claro desatendimento à Constituição (zona de certeza negativa) (BRASIL, 1994b, p. 32.312).

Na esteira da decisão da 2. " Turma do STJ no julgamento do RMS 23.402/PR, verifica-se a utilização de uma zona de certeza positiva quando se entendeu que a "falta de competitividade que se vislumbra pela só participação de duas empresas, com ofertas em valor bem aproximado ao limite máximo estabelecido", autoriza revogação de licitação (BRASIL, 2008c). Ipso facto, a participação de só dois licitantes caracteriza falta de competitividade, e esta configura interesse público apta a justificar a sua revogação.

\subsection{REDUÇÃO DA DISCRICIONARIEDADE A ZERO}

Ainda a respeito dos conceitos jurídicos indeterminados, desenvolveu-se na Alemanha a teoria da redução da discricionariedade a zero (Ermessensreduzierung auf Null), segundo a qual o poder de escolha do administrador pode deixar de existir diante das especificidades do caso concreto, por só haver uma única solução 
conforme o direito (BINENBOJM, 2014, p. 228).

Partidário dessa concepção, Harmut Maurer (2006, p. 142-143) defende que:

[...] discricionariedade significa que a Administração tem a escolha sobre diferentes tipos de comportamento. No caso particular pode, todavia, a possibilidade de escolha reduzir-se a uma alternativa. Então esse é o caso, quando somente uma decisão é livre de vícios de discricionariedade, ao passo que todas as outras decisões conteriam vícios de discricionariedade. O administrador é, portanto, obrigado a "escolher" aquela decisão remanescente. Fala-se nesses casos de "redução de discricionariedade a zero", ou de "diminuição da discricionariedade".

Segundo Andreas Krell (2004, p. 215-216), a doutrina germânica da "atrofia do poder discricionário" (Ermessensreduzierung auf Null) parte da ideia de que, "[...] quando circunstâncias normativas e fáticas do caso concreto diminuem bastante a possibilidade de escolha entre diversas opções, indicando fortemente para uma determinada solução", não há mais poder de escolha, como é próprio da discricionariedade. Como quando:

[...] quase todas as demais possibilidades de decisão estariam viciadas, sendo a autoridade administrativa obrigada a tomar uma decisão bastante predeterminada. As circunstâncias de fato, a práxis administrativa e, sobretudo, os direitos fundamentais, representam uma base para essa redução da discricionariedade.

Essa teoria, segundo se constatou na Alemanha a partir da década de 70, possui o efeito deletério de levar a "[...] uma excessiva e indesejável judicialização da atividade administrativa" (BINENBOJM, 2014, p. 229), até porque essa única solução adequada pode ser buscada a partir de princípios como a razoabilidade e a proporcionalidade (FERNANDES, 2009, p. 39), sendo que também estas se expressam em conceitos abertos.

É possível identificar, na jurisprudência dos Tribunais, diversos precedentes em que a teoria foi invocada. No julgamento do RE 837.311, sob o regime de repercussão geral, tendo como relator o Ministro Luiz Fux, o STF firmou o entendimento de que os candidatos aprovados fora do número de vagas previstas no edital não possuem, como regra, direito subjetivo à nomeação, mas somente se houver preterição ou recusa imotivada em nomear. Assentou-se, então, que: 
[...] a discricionariedade da Administração quanto à convocação de aprovados em concurso público fica reduzida ao patamar zero (Ermessensreduzierung auf Null), fazendo exsurgir o direito subjetivo à nomeação, verbi gratia, nas seguintes hipóteses excepcionais: i) Quando a aprovação ocorrer dentro do número de vagas dentro do edital (RE 598.099); ii) Quando houver preterição na nomeação por não observância da ordem de classificação (Súmula 15 do STF); iii) Quando surgirem novas vagas, ou for aberto novo concurso durante a validade do certame anterior, e ocorrer a preterição de candidatos aprovados fora das vagas de forma arbitrária e imotivada por parte da administração nos termos acima. [...] (BRASIL, 2014c).

De forma similar, a 2. ${ }^{\text {a }}$ Turma do STJ, ao julgar o REsp 879.188/RS, sendo relator o Ministro Humberto Martins (BRASIL, 2009), sustentou que "[...]o grau de liberdade inicialmente conferido em abstrato pela norma pode afunilar-se diante do caso concreto, ou até mesmo desaparecer [...]", mas se ressaltou que "é na dúvida que compete ao administrador, e somente a ele, escolher a melhor forma de agir."

Situação especial diz respeito aos direitos previstos constitucionalmente. Quanto a estes, a jurisprudência caminha claramente no sentido de afastar a discricionariedade administrativa quanto à sua implementação, ou seja, adota-se a implementação dos direitos constitucionais como a única solução possível, embora sem expressa menção à teoria germânica de Ermessensreduzierung auf Null.

Ao julgar o Agravo Regimental em Agravo em Recurso Extraordinário $n$. 639.337, a 2. ${ }^{\text {a }}$ Turma do STF, sob a relatoria do Ministro Celso de Mello, assentou que, embora a formulação de políticas pública seja a priori incumbência dos Poderes Legislativo e Executivo, inexiste discricionariedade quanto às "políticas públicas definidas pela própria Constituição". Assim:

[...] a educação infantil, por qualificar-se como direito fundamental de toda criança, não se expõe, em seu processo de concretização, a avaliações meramente discricionárias da Administração Pública nem se subordina a razões de puro pragmatismo governamental (BRASIL, 2011d).

A casuística revela que em diversos outros julgados se chegou a igual solução, sempre afastando a existência de discricionariedade quando em pauta direitos ou políticas públicas previstos na Constituição. Assim, obrigou-se o Poder Público, dentre outras medidas, a fornecer atendimento em creche e pré-escola (BRASIL, 2005e) de tratamento médico-cirúrgico a crianças e adolescentes (BRASIL, 2004) e a disponibilizar vagas em UTI's ((BRASIL, 2011b). Também com fundamento 
constitucional, foram proferidas decisões no sentido de assegurar direitos inerentes à dignidade da pessoa humana (BRASIL, 2010), inclusive em tema de superlotação de cadeia pública (BRASIL, 2014b).

\section{TEORIA DO ENFOQUE JURÍDICO-FUNCIONAL}

As construções doutrinárias vinham sempre andando no sentido de reduzir ou mesmo suprimir a margem de apreciação do administrador quanto aos atos discricionários, que em certos casos passariam à condição de vinculados. A teoria do enfoque jurídico-funcional rompe, de certa forma, esse ciclo, pois reconhece áreas e situações em que o controle judicial deve ser menos intenso.

O enfoque jurídico-funcional (funktionell-rechtliche Betrachtungsweise) parte da ideia de que o princípio da separação dos poderes deve receber uma releitura (KRELL, 2004, p. 45), de sorte que:

[...] ao invés de uma predefinição estática [...] impõe-se o estabelecimento de critérios de uma dinâmica distributiva "funcionalmente adequada" de tarefas e responsabilidades entre Administração e Judiciário, que leve em conta não apenas a programação normativa do ato a ser praticado (estrutura dos enunciados normativos constitucionais, legais ou regulamentares incidentes ao caso), como também a "específica idoneidade (de cada um dos Poderes) em virtude de sua estrutura orgânica, legitimação democrática, meios e procedimentos de atuação, preparação técnica etc., [...]" (BINENBOJM, 2014, p. 241).

Essa teoria parte de referenciais próximos àqueles utilizados pela teoria das capacidades institucionais desenvolvida por Cass Sunstein e Adrian Vermeule (2002, p. 2), ao sustentar que, para situações como as mais complexas envolvendo discricionariedade administrativa, os critérios tradicionais da interpretação jurídica não oferecem soluções satisfatórias:

[...] é impossível deduzir, a partir de reivindicações de grande escala, uma resposta a uma disputa sobre o significado da frase "causar câncer", ou Parte do nosso objetivo aqui é demonstrar a inutilidade dos esforços no emprego de ideais abstratos para resolver disputas sobre métodos interpretativos adequados. Em contrapartida, insistimos em que é muito mais promissor se concentrar em dois problemas negligenciados. O primeiro tem a ver com as 


\begin{abstract}
capacidades institucionais. [...], os debates sobre a interpretação jurídica não podem ser resolvidos sensatamente sem atenção a essas capacidades. [...] a questão é "como algumas instituições, com suas habilidades e limitações distintas, interpretam certos textos?" Se os juízes relevantes puderem decidir de forma confiável se uma interpretação literal de um termo estatutário é absurda, o argumento para rejeitar o literalismo é muito fortalecido; Se os juízes relevantes são altamente falíveis, o literalismo pode ter algumas virtudes negligenciadas. [...] A segunda questão envolve os efeitos dinâmicos de qualquer abordagem específica - suas consequências para atores particulares e públicos de vários tipos. Se uma interpretação não literal da frase 'induzir câncer' introduziria uma grande incerteza no sistema e reduziria o incentivo do Congresso para fazer correções, talvez seja sensato negar exceções em casos envolvendo riscos triviais. (grifos do autor).
\end{abstract}

Essa teoria preconiza, então, que a intepretação do direito pelos órgãos estatais deve considerar os elementos institucionais, em especial (i) a forma de atuação (decisões concretas ou edição de normas abstratas e genéricas); (ii) a composição do órgão (forma de provimento, expertise ou legitimação democrática); (iii) a capacidade de estabelecer prognóstico sobre o tema decidido; e (iv) habilitação/legitimidade para fazer certas escolhas e estabelecer prioridades ("escolhas trágicas" em tema de políticas públicas) (BINENBOJM, 2014, p. 242-243).

Assim, a extensão ou densidade do controle não se pauta por uma lógica puramente normativa, devendo atentar para os procedimentos adotados pela Administração e para as competências e responsabilidades dos órgãos decisórios. Logo, o controle tende a ser menos intenso (i) quando o ato foi precedido de um procedimento amplo, com efetiva participação dos administrados na decisão; (ii) em áreas técnicas, que lidam com matérias de alta complexidade, à falta de parâmetros objetivos para a atuação do Judiciário (expertise e experiência dos órgãos administrativos); e (iii) quando o ato carrega em si uma relevância política, a ponto de demandar a atuação do agente legitimado democraticamente.

A jurisprudência, embora sem fazer alusão expressa à teoria em questão, já tem se utilizado do fundamento jurídico subjacente a ela, tal como se vê do julgamento da ADPF n. 347 pelo Pleno do STF, relator o Ministro Marco Aurélio (BRASIL, 2015c), em que se reconheceu a necessidade de a atuação judicial se compatibilizar com a legitimidade e a especialização dos outros Poderes. É o que se extrai do voto do relator, quando diz que o Supremo deve relegar aos Poderes Executivo e Legislativo "o campo democrático e técnico de escolhas sobre a forma mais adequada para a superação do estado de inconstitucionalidades, vindo apenas a colocar a máquina 
estatal em movimento e cuidar da harmonia dessas ações".

Em sentido similar, ao analisar a questão relativa à redução do campo eletromagnético de suas linhas de transmissão pelas concessionárias de distribuição de energia, o Pleno do STF assentou que

[...] não há vedação para o controle jurisdicional das políticas públicas sobre a aplicação do princípio da precaução, desde que a decisão judicial não se afaste da análise formal dos limites desses parâmetros e que privilegie a opção democrática das escolhas discricionárias feitas pelo legislador e pela Administração Pública. [...]. (BRASIL, 2016a).

No julgamento do REsp 1.162.281/RJ, a $3^{\text {a }}$ Turma do STJ, sob a relatoria da Ministra Nancy Andrighi (BRASIL, 2013), entendeu que o Poder Judiciário não poderia se substituir ao Instituto Nacional de Propriedade Intelectual (INPI) na análise de processo de registro de marca de alto renome, por envolver tal competência o exercício de uma discricionariedade técnica.

Em outros julgados do próprio STJ, reconheceu-se a impossibilidade de interferência na atividade regulatória desenvolvida pela Agência Nacional de Saúde (ANS), respaldada em discricionariedade técnica (BRASIL, 2005c), assim como na atividade de fixação de limites de velocidade nas vias de trânsito, dado o caráter eminentemente técnico da questão (BRASIL, 2005d).

Ou seja, as premissas inerentes à doutrina do enfoque jurídico-funcional já têm sido gradualmente observadas pelos precedentes do STJ e do STF, embora não tenha havido até agora alusão expressa à mesma e, de mais e mais, uma sistematização mais rigorosa a respeito.

\section{CONCLUSÃO}

O tema relativo ao controle jurisdicional da discricionariedade administrativa está sujeito a uma evolução cíclica, pois é possível identificar uma clara sobreposição de teorias, ora no sentido de ampliar a sindicabilidade jurisdicional, ora buscando assegurar um espaço de livre apreciação para a autoridade administrativa.

Há, com efeito, um número espantoso de trabalhos acadêmicos a respeito do 
tema, com o desenvolvimento de teorias as mais diversas, assim como uma larga quantidade de precedentes judiciais em que são utilizados parâmetros sem a devida sistematização. A despeito disso, subsiste a grande dificuldade em delimitar o espaço de legítimo exercício do poder discricionário.

Mesmo com essas dificuldades, é possível verificar uma tendência de sistematização por parte de alguns estudiosos, como o faz Gustavo Binenbojm, no sentido de apontar, a partir da conjugação de diferentes doutrinas e da jurisprudência existente, alguns parâmetros para o controle jurisdicional da discricionariedade administrativa: (1) pode-se perceber, pela análise acima realizada, a relevância de se considerar que, quanto maior o grau de objetividade da norma, mais o controle judicial de ser intensificado. E isso pois tal objetividade é inversamente proporcional à discricionariedade do ente administrativo; (2) outro ponto relevante é que, geralmente, quanto maior for o grau de tecnicidade da matéria, menos intenso deve ser o controle judicial, tendo em vista que, ao ente administrativo, na maioria dos casos, confere-se maior expertise e experiência para a escolha da decisão do que o Poder Judiciário; (3) Também defende-se que, quanto maior o grau de politicidade da matéria no caso objeto de decisão por agente administrativo, menos intenso deve ser o grau de controle judicial. Sabe-se, por outro lado, da dificuldade de se estruturar taxativamente quais seriam esses casos. Isso porque, conforme já referido, muitas vezes a determinação do que é uma decisão especificamente política, ou do que é uma decisão cunhada em pressupostos legais, não é tarefa fácil, especialmente quando essa questão envolve princípios normativos e enunciados dotados de termos relativamente abstratos. Especificamente quanto aos conceitos jurídicos indeterminados, é cada vez mais recomendável que os tribunais atuem exercitando a autocontenção (judicial self-restraint), em especial quando o controle estiver incidindo sobre a denominada zona de penumbra; (4) Vale salientar também o pressuposto de que, quanto maior o grau de participação social no processo de deliberação do qual resultou a decisão, menos intenso deve ser o controle judicial. Esses termos são prementes para o fomento de que decisões o mais possível democráticas permeiem os órgãos estatais e suas escolhas. Vale observar que, mesmo democraticamente substanciada a decisão, ela pode ferir cláusulas pétreas constitucionais e/ direitos humanos fundamentais, o que deve ser levado em consideração para a possibilidade 
de exação judiciária; (5) Por fim, quanto maior o grau de restrição a direitos fundamentais, mais intenso deve ser o controle judicial, e isso se dá claramente pela necessidade de proteção desses direitos em prol da garantia da Constituição, do Estado Democrático de Direito e da dignidade a todos.

\section{REFERÊNCIAS}

BARROSO, Luís Roberto; BARCELOS, Ana Paula de. O começo da história. A nova interpretação constitucional e o papel dos princípios no Direito brasileiro. Revista da EMERJ, v. 6, n. 23, p. 25-65, 2003.

BINENBOJM, Gustavo. Uma teoria do direito administrativo. Direitos fundamentais, democrática e constitucionalização, 3. ed. Rio de Janeiro: Renovar, 2014.

BRASIL. Supremo Tribunal Federal, Tribunal Pleno, RE 62731, Relator Min. Aliomar Baleeiro, DJ 28 jun. $1968 . \quad$ Disponível http://redir.stf.jus.br/paginadorpub/paginador.jsp?docTP=AC\&doclD=159945 Acesso em 19 mar. 2019.

. Superior Tribunal de Justiça. Mandado de Segurança n. 85/DF. Relator Min. Carlos Velloso. 29 ago. 1989. Disponível em https://ww2.stj.jus.br/processo/ita/listarAcordaos?classe=\&num processo=\&num reg istro=198900103393\&dt publicacao=19/03/1990 Acesso em 19 mar. 2019.

Superior Tribunal de Justiça. Recurso Ordinário em Mandado de Segurança n. 1.751/PR. Relator Min. Américo Luz. 27 abr. 1994a. Disponível em https://ww2.stj.jus.br/processo/ita/listarAcordaos?classe=\&num processo=\&num reg istro=199200131719\&dt publicacao=13/06/1994 Acesso em 19 mar. 2019.

. Supremo Tribunal Federal. Recurso extraordinário n. 167.137/TO. Relator Min. Paulo Brossard. 18 out. 1994b. Disponível em http://redir.stf.jus.br/paginadorpub/paginador.jsp?docTP=AC\&doclD=216383 Acesso em 19 mar. 2019.

. Superior Tribunal de Justiça. Recurso Especial n. 52.082/DF. Relator Min. Demócrito Reinaldo. 12 nov. 1998. Disponível em https://ww2.stj.jus.br/processo/ita/listarAcordaos?classe=\&num processo=\&num reg istro=199400236689\&dt publicacao=08/03/1999 Acesso em 19 mar. 2019.

Superior Tribunal de Justiça. Recurso Ordinário em Mandado de Segurança n. 13.617/MG. Relator Min. Laurita Vaz. 12 mar. 2002. Disponível em https://ww2.stj.jus.br/processo/revista/inteiroteor/?num registro=200101015630\&dt publicacao=22/04/2002 Acesso em 19 mar. 2019. 
. Superior Tribunal de Justiça. Recurso Especial n. 443.310/RS. Relator Min. Luiz $\quad$ Fux. 212003.2003 Disponível https://ww2.sti.jus.br/processo/revista/inteiroteor/?num registro=200200778744\&dt publicacao=03/11/2003 Acesso em 19 mar. 2019.

. Superior Tribunal de Justiça. Recurso Especial n. 577.836/SC. Relator Min. Luiz $\quad$ Fux. $21 \quad$ out. 2004.2 Disponível em https://ww2.sti.jus.br/processo/revista/inteiroteor/?num registro=200301454392\&dt publicacao=28/02/2005 Acesso em 19 mar. 2019.

. Superior Tribunal de Justiça. Mandado de Segurança n. 9.944/DF. Relator Min. Teori Albino Zavascki. 25 mai. 2005a. Disponível em https://ww2.sti.jus.br/processo/revista/inteiroteor/?num registro=200401224610\&dt publicacao=13/06/2005 Acesso em 19 mar. 2019.

. Superior Tribunal de Justiça. Recurso Especial n. 725.537/RS. Relator Min. Félix Fischer. 19 mai. 2005b. Disponível em https://ww2.sti.jus.br/processo/revista/inteiroteor/?num registro=200500241226\&dt publicacao=01/07/2005 Acesso em 19 mar. 2019.

Superior Tribunal de Justiça. Agravo Regimental na Suspensão de Liminar de Segurança n. 163/PE. Relator Min. Edson Vidigal. 19 dez. 2005c. Disponível

em https://ww2.sti.jus.br/processo/revista/inteiroteor/?num registro=200500241226\&dt publicacao=01/07/2005 Acesso em 19 mar. 2019.

. Superior Tribunal de Justiça. Recurso Especial n. 588.253/RJ. Relator Min. Peçanha Martins. 18 ago. 2005d. Disponível em https://ww2.sti.jus.br/processo/revista/inteiroteor/?num registro=200301570086\&dt publicacao=17/10/2005 Acesso em 19 mar. 2019.

Supremo Tribunal Federal. Agravo Regimental no Recurso Extraordinário n. 410.715. Relator Min. Celso de Mello. 22 nov. 2005e. Disponível em http://redir.stf.jus.br/paginadorpub/paginador.jsp?docTP=AC\&doc/D=354801 Acesso em 19 mar. 2019.

Superior Tribunal de Justiça. Mandado de Segurança n. 10.597. Relator Min. João Otávio de Noronha. 22 out. 2007. Disponível em https://ww2.sti.jus.br/processo/revista/inteiroteor/?num registro=200500671425\&dt publicacao=22/10/2007 Acesso em 19 mar. 2019.

Superior Tribunal de Justiça. Mandado de Segurança n. 13.716/DF. Relator Min. Félix Fischer. 15 dez. 2008a. Disponível em https://ww2.sti.jus.br/processo/revista/inteiroteor/?num registro=200801670309\&dt publicacao=13/02/2009 Acesso em 19 mar. 2019.

. Superior Tribunal de Justiça. Recurso Especial n. 778.648/PE. Relator Min. Mauro Campbell Marques. 06 nov. 2008b. Disponível em https://ww2.sti.jus.br/processo/revista/inteiroteor/?num registro=200501463957\&dt 
publicacao=01/12/2008 Acesso em 19 mar. 2019.

Superior Tribunal de Justiça. Recurso Ordinário em Mandado de Segurança n. 23.402/PR. Relator Min. Eliana Calmon. 18 mar. 2008c. Disponível em https://ww2.sti.jus.br/processo/revista/inteiroteor/?num registro=200602710804\&dt publicacao=02/04/2008 Acesso em 19 mar. 2019.

. Superior Tribunal de Justiça. Recurso Especial n. 879.188/RS. Relator Min. Humberto Martins. 21 mai. 2009. Disponível em https://ww2.sti.jus.br/processo/revista/inteiroteor/?num registro=200601863236\&dt publicacao=02/06/2009 Acesso em 19 mar. 2019.

. Superior Tribunal de Justiça. Recurso Especial n. 1.185.474/SC. Relator Min. Humberto Martins. 20 abr. 2010. Disponível em https://ww2.sti.jus.br/processo/revista/inteiroteor/?num registro=201000486284\&dt publicacao=29/04/2010 Acesso em 19 mar. 2019.

Superior Tribunal de Justiça. Mandado de Segurança n. 15.334/SP. Relator Min. Cesar Asfor Rocha. 22 jun. 2011a. Disponível em https://ww2.sti.jus.br/processo/revista/inteiroteor/?num registro=201000969590\&dt publicacao=05/08/2011 Acesso em 19 mar. 2019.

. Superior Tribunal de Justiça. Recurso Especial n. 1.068.731/RS. Relator Min. Herman Benjamin. Brasília, 17 fev. 2011b. Disponível em https://ww2.sti.jus.br/processo/revista/inteiroteor/?num registro=200801379303\&dt publicacao=08/03/2012 Acesso em 19 mar. 2019.

Supremo Tribunal Federal. Recurso extraordinário n. 598.099. Relator Min. Gilmar Mendes. 10 ago. 2011c. Disponível em http://redir.stf.jus.br/paginadorpub/paginador.jsp?docTP=AC\&doclD=628215 Acesso em 19 mar. 2019.

. Supremo Tribunal Federal. 2. ${ }^{\text {a }}$ Turma, ARE 639.337 AgR, Relator Min. Celso de Mello, DJe 14 set. 2011d. Disponível em http://redir.stf.jus.br/paginadorpub/paginador.jsp?docTP=AC\&doclD=627428 Acesso em 19 mar. 2019.

. Superior Tribunal de Justiça. Agravo Regimental no Recurso Especial $\mathbf{n}$. 1.280.729/RJ. Relator Min. Humberto Martins. 10 abr. 2012. Disponível em https://ww2.sti.jus.br/processo/revista/inteiroteor/?num registro=201101763271\&dt publicacao=19/04/2012 Acesso em 19 mar. 2019.

. Superior Tribunal de Justiça. Recurso Especial n. 1.162.281/RJ. Relator Min. Nancy Andrighi. 19 fev. 2013. Disponível em https://ww2.sti.jus.br/processo/revista/inteiroteor/?num registro=200902075272\&dt publicacao=25/02/2013 Acesso em 19 mar. 2019. 
Especial n. 500.567/CE. Relator Min. Herman Benjamin. 18 jun. 2014a. Disponível em

https://ww2.sti.jus.br/processo/revista/inteiroteor/?num registro=201400822794\&dt publicacao=18/08/2014 Acesso em 19 mar. 2019.

. Superior Tribunal de Justiça. Recurso Especial n. 1.389.952/MT. Relator Min. Herman Benjamin. 03 jun. 2014b. Disponível em https://ww2.sti.jus.br/processo/revista/inteiroteor/?num registro=201301926710\&dt publicacao=07/11/2016 Acesso em 19 mar. 2019.

. Supremo Tribunal Federal. Tribunal Pleno, RE 837311 RG, Relator Min. Luiz Fux, DJe 01 dez. 2014c. Disponível em http://redir.stf.jus.br/paginadorpub/paginador.jsp?docTP=TP\&doclD=10744965 Acesso em 19 mar. 2019.

Supremo Tribunal Federal. Recurso extraordinário n. 837.311. Relator Min. Luiz Fux Brasília, 09 dez. 2015a. Disponível em http://redir.stf.jus.br/paginadorpub/paginador.jsp?docTP=TP\&doclD=10744965 Acesso em 19 mar. 2019.

Supremo Tribunal Federal. Agravo Regimental no Agravo no Recurso extraordinário n. 639.377. Relator Min. Luiz Fux. 09 dez. 2015b. Disponível em http://redir.stf.jus.br/paginadorpub/paginador.jsp?docTP=TP\&doclD=1386607 Acesso em 19 mar. 2019.

Supremo Tribunal Federal. Medida Cautelar na Arguição de Descumprimento de Preceito Fundamental n. 347. Relator Min. Marco Aurélio. 09 set. 2015c. Disponível em http://redir.stf.jus.br/paginadorpub/paginador.jsp?docTP=TP\&doclD=10300665 Acesso em 19 mar. 2019.

. Supremo Tribunal Federal. Recurso Extraordinário n. 627.189. Relator Min. Dias Tofolli. 08 jun. 2016a. Disponível em http://redir.stf.jus.br/paginadorpub/paginador.jsp?docTP=TP\&doclD $=12672680$ Acesso em 19 mar. 2019.

Superior Tribunal de Justiça. Mandado de Segurança n. 21.807/DF. Relator Min. Assusete Magalhães. 24 fev. 2016b. Disponível em https://ww2.sti.jus.br/processo/revista/inteiroteor/?num registro=201501291192\&dt publicacao=15/03/2016 Acesso em 19 mar. 2019.

Supremo Tribunal Federal. Recurso extraordinário n. 898.450. Relator Min. Luiz Fux. 30 mai. 2017. Disponível em http://redir.stf.jus.br/paginadorpub/paginador.jsp?docTP=TP\&doclD=12977132 Acesso em 19 mar. 2019.

DALLARI, Adilson. A autoridade coatora. In: MELLO, Celso Antônio B. de (coord.). Curso de mandado de segurança. São Paulo: Revista dos Tribunais, 1986. 
DI PIETRO, Maria Sylvia Z. Direito administrativo. 22. ed. São Paulo: Atlas, 2009.

A constitucionalização do direito administrativo - Reflexos sobre o princípio da legalidade e a discricionariedade administrativa. Atualidades Jurídicas: Revista do Conselho Federal da Ordem dos Advogados do Brasil - OAB. Belo Horizonte, ano 2, n. 2, jan./jun. 2012.

FERNANDES, André D. Da aplicação dos princípios da proporcionalidade e da razoabilidade no controle jurisdicional dos atos administrativos. Revista Esmafe. Recife, v. 3, n. 19 (edição especial), p. 9-56, 2009.

GUERRA, Sérgio. Discricionariedade, regulação e reflexidade - uma nova teoria sobre as escolhas administrativas, 3. ed. Belo Horizonte: Fórum, 2015.

KRELL, Andreas. A recepção das teorias alemãs sobre "conceitos jurídicos indeterminados" e o controle da discricionariedade no Brasil. Interesse público, v. 5, n. 23. Belo Horizonte, jan./fev., 2004.

- Discricionariedade administrativa, conceitos jurídicos indeterminados e controle judicial. Revista Esmafe, Recife, n. 8, p. 177-224, dez. 2004a.

Discricionariedade administração e proteção ambiental: o controle dos conceitos jurídicos indeterminados e a competência dos órgãos ambientais: um estudo comparativo. Porto Alegre: Livraria do Advogado, 2004b.

MAURER, Hartmut. Allgemeines Verwaltungsrecht. 16. ed. München: C.H. Beck, 2006.

MEDAUAR, Odete. Direito administrativo moderno, 6. ed. São Paulo: RT, 2002.

MELLO, Celso Antônio B. de. Curso de direito administrativo, 29. ed. rev. e atual. São Paulo: Malheiros, 2011.

Discricionariedade administrativa e controle jurisdicional, 2. ed., 3. tir. São Paulo: Malheiros, 1998.

Pareceres de direito administrativo. São Paulo: Malheiros, 2011.

MORAES, Germana de O. Controle jurisdicional da Administração Pública. São Paulo: Dialética, 2004.

RAZ, Joseph. The authority of law: essays on law and morality. New York: Clarendon Press, 1979.

ROMAN, Flávio José. Discricionariedade técnica. In: CAMPILONGO, Celso F.; GONZAGA, Alvaro de A.; FREIRE, André Luiz. (coords.). Enciclopédia jurídica da PUC-SP. São Paulo: Pontifícia Universidade Católica de São Paulo, 2017. Disponível em: $\quad$ https://enciclopediajuridica.pucsp.br/verbete/148/edicao-1/discricionariedade- 
tecnica Acesso em 01 mar. 2019.

SILVA, Almiro do C. Poder discricionário no direito administrativo brasileiro. Revista de direito administrativo, v. 179, p. 51-67, 1990.

SUNSTEIN, Cass; VERMEULE, Adrian. Interpretation and institutions, John M. Olin program in law and economics working paper, $\mathrm{n} .156,2002$. Disponível em: http://www.law.uchicago.edu/Publications/Working/index.html Acesso em: 01 mar. 2019.

QUEIRÓ, Afonso R. A teoria do "desvio de poder" em direito administrativo. Revista de direito administrativo, v. 6, p. 41-78, 1946.

TÁCITO, Caio. O desvio de poder no controle dos atos administrativos, legislativos e jurisdicionais. Revista de direito administrativo, v. 242, p. 63-74, 1992.

VIEIRA, Oscar V. Estado de Direito. In: CAMPILONGO, Celso F.; GONZAGA, Alvaro de A.; FREIRE, André Luiz. (coords.). Enciclopédia jurídica da PUC-SP. Tomo: Teoria Geral e Filosofia do Direito. São Paulo: Pontifícia Universidade Católica de São Paulo, 2017. Disponível em: https://enciclopediajuridica.pucsp.br/verbete/78/edicao1/estado-de-direito Acesso em 01 mar. 2019. 